\title{
Strain-specificity in the hydrogen sulphide signalling network following dietary restriction in recombinant inbred mice
}

\author{
Stephen E. Wilkie • Lorna Mulvey • William A. Sands • Diana E. Marcu • Roderick N. \\ Carter • Nicholas M. Morton • Christopher Hine • James R. Mitchell • Colin Selman $\mathbb{B}$
}

Received: 4 October 2019 / Accepted: 11 February 2020 /Published online: 11 March 2020

(C) The Author(s) 2020

\begin{abstract}
Modulation of the ageing process by dietary restriction (DR) across multiple taxa is well established. While the exact mechanism through which DR acts remains elusive, the gasotransmitter hydrogen sulphide $\left(\mathrm{H}_{2} \mathrm{~S}\right)$ may play an important role. We employed a comparative-type approach using females from three ILSXISS recombinant inbred mouse strains previously reported to show differential lifespan responses following $40 \%$ DR. Following long-term (10 months) $40 \%$ DR, strain TejJ89 - reported to show lifespan extension under DR - exhibited elevated hepatic $\mathrm{H}_{2} \mathrm{~S}$ production relative to its strain-specific ad libitum (AL) control.
\end{abstract}

Electronic supplementary material The online version of this article (https://doi.org/10.1007/s11357-020-00168-2) contains supplementary material, which is available to authorized users.

S. E. Wilkie · L. Mulvey • W. A. Sands • D. E. Marcu •

C. Selman $(\bowtie)$

Glasgow Ageing Research Network (GARNER), Institute of Biodiversity, Animal Health and Comparative Medicine, College of Medical, Veterinary and Life Sciences, University of Glasgow, Glasgow G12 8QQ, UK

e-mail: Colin.Selman@glasgow.ac.uk

\section{R. N. Carter · N. M. Morton}

Molecular Metabolism Group, University/BHF Centre for Cardiovascular Sciences, Queens Medical Research Institute, University of Edinburgh, Edinburgh EH16 4TJ, UK

C. Hine

Department of Cardiovascular and Metabolic Sciences, Cleveland Clinic Lerner Research Institute, Cleveland, OH 44195, USA

J. R. Mitchell

Department of Genetics and Complex Diseases, Harvard T.H.

Chan School of Public Health, Boston, MA 02115, USA
Strain TejJ48 (no reported lifespan effect following $40 \%$ DR) exhibited significantly reduced hepatic $\mathrm{H}_{2} \mathrm{~S}$ production, while $\mathrm{H}_{2} \mathrm{~S}$ production was unaffected by DR in strain TejJ114 (shortened lifespan reported following $40 \%$ DR). These differences in $\mathrm{H}_{2} \mathrm{~S}$ production were reflected in highly divergent gene and protein expression profiles of the major $\mathrm{H}_{2} \mathrm{~S}$ production and disposal enzymes across strains. Increased hepatic $\mathrm{H}_{2} \mathrm{~S}$ production in TejJ89 mice was associated with elevation of the mitochondrial $\mathrm{H}_{2} \mathrm{~S}$-producing enzyme 3mercaptopyruvate sulfurtransferase (MPST). Our findings further support the potential role of $\mathrm{H}_{2} \mathrm{~S}$ in DRinduced longevity and indicate the presence of genotypic-specificity in the production and disposal of hepatic $\mathrm{H}_{2} \mathrm{~S}$ in response to $40 \%$ DR in mice.

Keywords Caloric restriction · Ageing - ILSXISS Longevity $\cdot$ Sulphide $\cdot$ Dietary restriction $\cdot 3$ mercaptopyruvate sulfurtransferase

\section{Introduction}

Empirical evidence has existed for over a century that dietary restriction (DR) increases lifespan and healthspan across multiple species (Fontana and Partridge 2015; Picca et al. 2017; Weindruch and Walford 1988). In mice, significant strain-specific differences in lifespan exist (Turturro et al. 1999; Yuan et al. 2009) and genetic background may consequently play an important but under-appreciated role in how particular strains respond to DR (Hempenstall et al. 
2010; Ingram and de Cabo 2017; Mitchell et al. 2016; Mulvey et al. 2014; Selman and Swindell 2018; Swindell 2012). For example, two independent studies have reported that recombinant inbred ILSXISS mice show significant strain-specificity in longevity following 40\% DR (Liao et al. 2010; Rikke et al. 2010), and phenotypic parameters linked to the ageing process, such as in mitochondrial function and adiposity, have been shown to differ between ILSXISS strains under 40\% DR (Liao et al. 2011; Mulvey et al. 2016).

Precisely how DR facilitates its beneficial effects on lifespan and healthspan has proved challenging to elucidate, although many mechanisms have been proposed (Fontana and Partridge 2015; Hine and Mitchell 2015; Kennedy et al. 2007; Mair and Dillin 2008; Masoro 2005). One such putative mechanism is the gasotransmitter hydrogen sulphide $\left(\mathrm{H}_{2} \mathrm{~S}\right)$. Direct manipulation of $\mathrm{H}_{2} \mathrm{~S}$ levels through genetic, pharmacological or environmental means can modulate lifespan in invertebrate models (Hine and Mitchell 2015; Miller and Roth 2007; Qabazard et al. 2013; Shaposhnikov et al. 2018; Wei and Kenyon 2016) and elevated hepatic $\mathrm{H}_{2} \mathrm{~S}$ production appears to be a conserved phenotype in longlived mouse models, including DR and various genetic mutants (Hine et al. 2017; Mitchell et al. 2016). Pharmacological elevation of $\mathrm{H}_{2} \mathrm{~S}$ has also been shown to ameliorate age-associated atherosclerosis, fibrosis, cognitive decline and kidney dysfunction in rodents (Das et al. 2018; Lee et al. 2018; Zhan et al. 2018), and partially rescued a progeroid phenotype in Werner syndrome fibroblasts (Talaei et al. 2013) and senescence in endothelial cells (Latorre et al. 2018). Furthermore, DRinduced protection from ischemia-reperfusion injury was abrogated in mice treated with an inhibitor of cystathionase- $\gamma$-lyase (CSE), the major hepatic $\mathrm{H}_{2} \mathrm{~S}$ producing enzyme (Hine et al. 2015), and longevity in mice following methionine restriction was associated with increased $\mathrm{H}_{2} \mathrm{~S}$ production and a reduction in various senescence markers within the kidney (Wang et al. 2019). Consequently, it has been proposed that elevation of endogenous $\mathrm{H}_{2} \mathrm{~S}$ may play a prominent role in the lifespan and healthspan effects of DR (Hine and Mitchell 2015).

Here, we employed a comparative-type approach (Mulvey et al. 2016) in which we determined hepatic and kidney $\mathrm{H}_{2} \mathrm{~S}$ production, and hepatic transcript and protein levels of key enzymes involved in $\mathrm{H}_{2} \mathrm{~S}$ metabolism in female mice from three genetically distinct recombinant inbred ILSXISS strains exposed to long-term
(10 months) 40\% DR. These strains have previously been reported to show variable lifespan responses to $40 \%$ DR ranging from life extension to life shortening relative to strain-specific ad libitum controls (Liao et al. 2010; Rikke et al. 2010).

\section{Methods}

Animals

The ILSXISS strains TejJ89, TejJ48 and TejJ114 were purchased from the Jackson Laboratory (Bar Harbour, Maine, URL: http://www.informatics.jax.org) as breeding pairs and experimental cohorts subsequently bred at The University of Glasgow. As previously discussed (Mulvey et al. 2016), female mice from strains TejJ89, TejJ48 and TejJ114 showed repeatable directional effects (TejJ89 lifespan extension under dietary restriction (DR), TejJ48 lifespan unaffected under DR, TejJ114 lifespan shortening under DR) on lifespan following 40\% DR across 2 independent studies, but that no strain-specific differences in lifespan were reported when these mice were maintained on an ad libitum (AL) diet (Liao et al. 2010; Rikke et al. 2010). It should be noted that several potential shortcomings to the experimental design of these original studies have been raised (Selman and Swindell 2018), not least that $40 \%$ DR may simply be sub-optimal in TejJ48 and TejJ114, and that lifespan extension in these strains is likely to be seen at a higher or lower level of DR; these dose-response experiments are still to be undertaken (Selman and Swindell 2018). However, for the purposes of this study, we were interested in whether there was a relationship between $\mathrm{H}_{2} \mathrm{~S}$ production and reported lifespan following $40 \%$ DR. Female mice were used for all experiments because lifespan was only determined in female mice across both original studies (Liao et al. 2010; Rikke et al. 2010). In addition, we also examined components of the $\mathrm{H}_{2} \mathrm{~S}$ signalling network in female $\mathrm{C} 57 \mathrm{BL} / 6 \mathrm{~J}$ mice that followed a similar long-term $40 \%$ DR protocol, to further examine potential strain-specific effects. It has previously been shown that hepatic $\mathrm{H}_{2} \mathrm{~S}$ production is increased female $\mathrm{C} 57 \mathrm{BL} / 6 \mathrm{~J}$ mice under $40 \% \mathrm{DR}$ (Mitchell et al. 2016).

All mice were maintained from weaning onwards at $22 \pm 2{ }^{\circ} \mathrm{C}$ and on a $12 \mathrm{~L} / 12 \mathrm{D}$ cycle (lights on $0700-$ $1900 \mathrm{~h}$ ) in groups of 4 mice within shoebox cages $(48 \mathrm{~cm} \times 15 \mathrm{~cm} \times 13 \mathrm{~cm})$, with $\mathrm{AL}$ access to water 
and standard chow (CRM(P), Research Diets Services, LBS Biotech, UK; Atwater Fuel Energyprotein $22 \%$, carbohydrate $69 \%$, fat $9 \%$ ). $10 \%$ DR was introduced in a graded fashion from 10 weeks of age and then held at $40 \%$ DR from 12 weeks onwards, with the food intake of the DR cohorts adjusted each week relative to the average weekly AL food intake of the appropriate age-matched and strainspecific AL controls (Hempenstall et al. 2010; Mulvey et al. 2016). Following 10 months of $40 \%$ DR (13 months of age) female mice were fasted overnight and culled using cervical dislocation under a UK Home Office Project Licence (60/4504) and following the "principles of laboratory animal care" (NIH Publication No. 86-23, revised 1985). Tissues were immediately dissected out, snap-frozen in liquid nitrogen and stored at $-80{ }^{\circ} \mathrm{C}$ until use.

Hydrogen sulphide $\left(\mathrm{H}_{2} \mathrm{~S}\right)$ production

Measurement of $\mathrm{H}_{2} \mathrm{~S}$ production was performed in liver and kidney homogenates according to a previously described protocol (Hine and Mitchell 2017). Briefly, $100 \mathrm{mg}$ of flash-frozen liver and kidney were lysed in passive lysis buffer. Protein concentration was determined by BCA assay (G Biosciences, MO, USA) and $100 \mu \mathrm{g}$ of protein lysate was loaded into $96-$ well plate. A $150-\mu \mathrm{L}$ reaction solution containing $10 \mathrm{mM} \mathrm{L}$-cysteine and $1 \mathrm{mM}$ pyridoxal-5'-phosphate was added to the protein lysate. Filter paper that had previously been cut to the size of the plate, soaked in $20 \mathrm{mM}$ lead(II)acetate trihydrate for $20 \mathrm{~min}$, then dried under vacuum, was then securely attached to the plate. The assembled plate was incubated at $37{ }^{\circ} \mathrm{C}$ for $1 \mathrm{~h} . \mathrm{H}_{2} \mathrm{~S}$ sulphide gas produced during this time collects in the head space between the top of the solution in the well and the lead(II)acetate paper, forming a brown-black substrate on the paper. The amount of $\mathrm{H}_{2} \mathrm{~S}$ present in each sample was subsequently quantified by densitometry analysis (ImageJ) of the brown-black substrate.

\section{RNA extraction}

RNA was isolated from liver tissue by addition of $500 \mu \mathrm{L}$ of TRIzol (Life Technologies, USA) and subsequently homogenised using a glass-glass homogeniser. Samples were transferred to screw top Eppendorf tubes and $150 \mu \mathrm{L}$ of chloroform added. Samples were then spun by centrifuge at $8000 \mathrm{~g}$ and the supernatant containing the RNA isolate was taken to a fresh Eppendorf. RNA cleanup was performed according to instructions provided in RNAeasy Mini Kit (Qiagen, Germany), including the optional DNase digestion step.

\section{Reverse transcriptase quantitative-PCR}

First strand synthesis of cDNA was performed by incubating $2 \mu \mathrm{g}$ of RNA (quantified by spectrophotometry using Nanodrop 1000 UV-Vis spectrophotometer, ThermoScientific, MA, US) with $1 \mu \mathrm{g}$ Random Primer Mix (Invitrogen) in a total volume of $15 \mu \mathrm{L}$ with RNAse-free water at $70{ }^{\circ} \mathrm{C}$ for 5 min using a $\mathrm{MJ}$ research PTC-200 Peltier Thermal Cycler (Biorad, CA, US). Synthesis of cDNA was then performed by adding $10 \mu \mathrm{L}$ of master mix ( $1 \mu \mathrm{L}$ Promega M-MLV reverse transcriptase, $2 \mu \mathrm{L}$ Promega M-MLV $5 \mathrm{x}$ buffer, $5 \mu \mathrm{L}$ pooled $10 \mathrm{mM}$ dNTPs, $0.625 \mu \mathrm{L}$ RNAseOUT 40 units/ $\mu \mathrm{L}$ and $1.375 \mu \mathrm{L}$ nuclease free water) to the first stand sample and heating to $37^{\circ} \mathrm{C}$ for $1 \mathrm{~h}$. Samples were then diluted 1:1 with PCR-grade water and used directly for RT-qPCR. RT-qPCR was performed in a 384-well PCR plate. Each well contained $1 \mu \mathrm{l}$ of cDNA, $0.25 \mu \mathrm{L}$ $10 \mathrm{mM}$ upper primer, $0.25 \mu \mathrm{L} 10 \mathrm{mM}$ lower primer, $3.5 \mu \mathrm{L}$ of PCR-grade water and $5 \mu \mathrm{L}$ of QuantiFast SYBR green PCR 2x master mix (Qiagen, UK). PCR reaction was performed using a 7900HT Fast Real-Time PCR System (Applied Biosystems, CA, US). PCR profile was as follows: $95{ }^{\circ} \mathrm{C}$ for $5 \mathrm{~min} ; 94{ }^{\circ} \mathrm{C}$ for $30 \mathrm{~s}$, $60{ }^{\circ} \mathrm{C}$ for $30 \mathrm{~s}, 72^{\circ} \mathrm{C}$ for $30 \mathrm{~s}$ for 40 cycles; $72{ }^{\circ} \mathrm{C}$ for $5 \mathrm{~min}$. The endogenous control gene was $\beta 2 \mathrm{M}$, which has been previously shown to be an appropriate housekeeping control gene for mouse dietary restriction studies (Gong et al. 2016). Gene expression was calculated by subtracting the $\mathrm{Ct}$ value for $\beta 2 \mathrm{M}$ from the $\mathrm{Ct}$ value pertaining to the gene of interest in each sample. As such, a lower $\Delta \mathrm{Ct}$ indicates a higher relative gene expression of mRNA transcripts and vice versa. Primer sequences are provided in Table S1.

\section{Western blotting}

Protein lysate was obtained by homogenisation of liver tissue in $1 \mathrm{~mL}$ of ice cold RIPA buffer (Radio Immunoprecipitation Assay Buffer; $150 \mathrm{mM}$ sodium chloride, $1 \%$ NP-40 or Triton X-100, $0.5 \%$ sodium deoxycholate, $0.1 \%$ sodium dodecyl sulphate, 
$50 \mathrm{mM}$ Tris, $\mathrm{pH}$ 8) containing protease and phosphatase inhibitors (Halt ${ }^{\mathrm{TM}}$ Protease and Phosphatase Inhibitor Cocktail, Thermo Fisher Scientific, UK; phenylmethylsulfonyl fluoride, Sigma Life Sciences, Germany; Complete Mini EDTA-free protease inhibitor cocktail, Merck, NJ, US) using a glass-glass homogeniser. Homogenates were kept on ice for $40 \mathrm{~min}$ and then spun by centrifuge at $8000 \mathrm{~g}$ for $10 \mathrm{~min}$ at $4{ }^{\circ} \mathrm{C}$. The supernatant was collected and used as protein lysate. Protein concentration was assessed by BCA assay ( $\mathrm{G}$ Biosciences, MO, USA) and $20 \mu \mathrm{g}$ of protein was loaded per well into homemade $4-12 \%$ bis-tris polyacrylamide gels. Precision Plus Protein ${ }^{\mathrm{TM}}$ Dual Xtra Standards protein marker (BioRad, CA, US) were added to a well on each gel. Proteins were separated by electrophoresis at $90 \mathrm{~V}$ for $90 \mathrm{~min}$ and then transferred onto nitrocellulose membrane at $0.25 \mathrm{~V}$ for $1 \mathrm{~h}$. Membranes were stained with Ponceau-S (Sigma Life Sciences, Germany), briefly washed in deionised water and the resulting total protein stain was captured using a Chemidoc ${ }^{\mathrm{TM}}$ XRS System (BioRad, CA, US). The Ponceau-S stain was removed by using 1xTBST (Tris-Buffered Saline Tween ${ }^{20}$ ) and the membrane was blocked with $5 \%$ milk in $1 \times$ TBST for $40 \mathrm{~min}$. The membrane was washed 5 times with 1xTBST for 5 min under constant shaking. Primary antibodies (AbCam, Cambridge, UK) were added to the membrane in $5 \%$ BSA in 1xTBST. CSE (ab151769) primary antibody was used at 1:1000 dilution; CBS (ab135626) and MPST (ab85377) were used at 1:100. Primary antibodies were allowed to incubate with the membrane overnight at $4{ }^{\circ} \mathrm{C}$, under constant shaking. HRPlinked anti-rabbit antibody (\#7074; Cell Signalling Technology, London, UK) was used at 1:2000 dilution in 5\% BSA in 1xTBST as the secondary antibody for all blots. The secondary antibody was allowed to incubate with the membrane for $1 \mathrm{~h}$, under constant shaking. The membrane was washed 5 times with 1 XTBST for $5 \mathrm{~min}$, under constant shaking before addition of all antibodies and before imaging. For imaging, membranes were coated with ClarityTM Western ECL substrate (BioRad, CA, US) reagent and left to react for approx. $3 \mathrm{~min}$ before an image was developed under chemiluminescent conditions using a ChemiDoc ${ }^{\mathrm{TM}}$ XRS System. Protein signals were quantified using densitometry software (ImageStudio; LiCor, NE, US) and normalised to the total protein signal of their respective lane.
3-Mercaptopyruvate sulfurtransferase activity assay

3-Mercaptopyruvate sulfurtransferase (MPST) activity was determined in liver by measuring thiocyanate production capacity as described previously for thiosulfate sulfurtransferase (TST) rhodanese activity (Morton et al. 2016), except that sodium 3mercaptopyruvate (3-MP) was used as a substrate instead of sodium thiosulfate. In a 96-well plate, $20 \mu \mathrm{g}$ of protein lysate in RIPA was mixed with $10 \mu \mathrm{L} 200 \mathrm{mM}$ 3-MP (Santa-Cruz, UK) and taken to $90 \mu \mathrm{L}$ with $500 \mathrm{mM}$ potassium phosphate $\mathrm{pH} 5.5$ buffer. Samples were incubated at $37{ }^{\circ} \mathrm{C}$ for $2 \mathrm{~min}$ before addition of $10 \mu \mathrm{L} 500 \mathrm{mM}$ potassium cyanide. A calibration curve of 50, 25, 10, 5, 2.5, 1, 0.5, 0.25 and $0.1 \mathrm{mM}$ potassium thiocyanate solutions was also prepared and exposed to the same conditions as above, excluding the addition of potassium cyanide. The reaction was allowed to occur for $5 \mathrm{~min}$ at $37{ }^{\circ} \mathrm{C}$ before termination by addition of $11 \mu \mathrm{L}$ of $38 \%$ formaldehyde to all wells. Thiocyanate production was visualised by addition of $125 \mu \mathrm{L} \mathrm{Fe}\left(\mathrm{NO}_{3}\right)_{3} / 26 \% \mathrm{HNO}_{3}$ where an orangebrown solution formed. Results were quantified by measuring absorbance for $460 \mathrm{~nm}$ light in a spectrophotometer (Multiscan GO Microplate Spectrophotometer, Thermo Scientific, MA, USA). All samples were performed in duplicate and the average $460 \mathrm{~nm}$ absorbance was calculated.

\section{Statistical analysis}

All statistical analyses were performed using SPSS $®$ Version 25 (IBM®, New York, USA) and Prism 6 (GraphPad Inc., La Jolla, USA) software. All data were analysed using a general linear modelling approach with treatment (AL or DR) and genotype (TejJ89, TejJ48 and TejJ114 (and where indicated, C57BL/6J)) introduced as fixed factors, and a post hoc Bonferroni test used for multiple comparisons. In all cases, non-significant interactions ( $p>0.05$ ) within the GLM analyses were removed in order to obtain the best-fitting model, with only significant interactions reported. All data were analysed by Grubbs outlier test with alpha set to $5 \%$. Unless otherwise described, all results are presented as mean \pm standard error of the mean (SEM), with $p<0.05$ regarded as statistically significant. $*$ denotes $p<0.05$, ** denotes $p<0.01$ and $* * *$ denotes $p<0.001$. 


\section{Results}

Genotype-specific hepatic $\mathrm{H}_{2} \mathrm{~S}$ production following $40 \%$ DR in female ILSXISS mice

Using the lead acetate method to determine $\mathrm{H}_{2} \mathrm{~S}$ production (Hine et al. 2015; Hine et al. 2017), we observed a significant genotype effect $(F=12.243, p<0.001)$ but no treatment effect $(F=0.150, p=0.701)$ in the liver. However, a significant genotype by treatment interaction was detected $(F=13.833, p<0.001)$. Post hoc analysis indicated that $\mathrm{H}_{2} \mathrm{~S}$ production was significantly elevated by $40 \%$ DR in strain TejJ89 ( $p=0.005)$, but significantly reduced by $40 \%$ DR in strain TejJ48 ( $p=$ 0.031) relative to their strain-appropriate AL controls (Fig. 1a, b). In addition, $\mathrm{H}_{2} \mathrm{~S}$ production was significantly elevated in strain TejJ89 relative to strains TejJ48 $(p=0.022)$ and TejJ114 $(p<0.001)$. This genotype effect was primarily driven by significantly elevated $\mathrm{H}_{2} \mathrm{~S}$ production in TejJ89 under 40\% DR compared with all other groups, with no differences in $\mathrm{H}_{2} \mathrm{~S}$ production detected between ILSXISS strains under AL feeding (Fig. 1a, b). We also determined kidney $\mathrm{H}_{2} \mathrm{~S}$ production (Fig. S1). No significant treatment effect was detected $(F=1.540, p=0.0221)$, but a significant genotype effect on kidney $\mathrm{H}_{2} \mathrm{~S}$ production was seen $(F=3.294, p=$ 0.047), being significantly elevated in strain TejJ89 relative to strain TejJ48 $(p=0.050)$.

Transcript levels of $\mathrm{H}_{2} \mathrm{~S}$-production and -elimination proteins in ILSXISS mice following $40 \%$ DR

In order to better understand the enzymatic pathways regulating hepatic endogenous $\mathrm{H}_{2} \mathrm{~S}$ (see Fig. 2) across different ILSXISS strains maintained under $\mathrm{AL}$ or $40 \% \mathrm{DR}$, we determined gene expression levels of a suite of $\mathrm{H}_{2} \mathrm{~S}$-producing and eliminating proteins (Fig. 3a-i). Cse, Cbs and Mpst transcript levels (Fig. 3a-c) were unaffected by both genotype and treatment (see Table S2 for all statistical output). However, a significant genotype by treatment interaction effect was observed for both Cbs (Fig. 3b, $F=4.737, p=0.017$ ) and Mpst (Fig. $3 \mathrm{c}, F=6.734, p=0.004)$, with lower expression in strain TejJ89 under AL feeding relative to strain TejJ114 under AL feeding ( $p=0.008$ and $p=0.024$ for Cbs and Mpst respectively). Got1 (Fig. 3d) and Ethel expression (Fig. 3e) differed by genotype $(F=7.185, p=0.003$ and $F=10.445, p<0.001$ for
Got1 and Ethe1 respectively) but not by treatment, with strain TejJ48 having significantly lower Got1 and Ethe1 expression relative to strains TejJ89 and TejJ114 ( $p<0.01$, in all cases). Tst expression levels (Fig. 3f) showed a significant genotype effect $(F=$ $6.659, p=0.004)$, with reduced expression in liver of TejJ89 mice compared with TejJ114 mice ( $p=$ 0.003 ), but again no treatment effect was detected. A significant $T s t$ genotype by treatment interaction was also detected $(F=6.745, p=0.004)$, with AL TejJ89 mice having significantly lower $T_{s} t$ expression levels compared with AL TejJ114 mice $(p<0.001)$, and $40 \%$ DR reducing Tst expression in Tej114 mice $(p=0.007)$ relative to TejJ114 controls (Fig. 3f). While no significant genotype nor treatment effect on Suox expression was detected (Fig. $3 \mathrm{~g}$ and Table S2), a significant genotype by treatment interaction effect was observed $(F=5.694, p=0.008)$, again with AL TejJ89 mice having significantly reduced expression relative to AL TejJ114 mice $(p=$ 0.035 ), and $40 \%$ DR significantly reducing Suox expression in Tej114 mice relative to AL TejJ114 mice $(p=0.008)$. Mat1a (Fig. 3 h) did not show any significant genotype effect $(F=1.069, p=0.356)$ but was the only transcript that showed a significant treatment effect $(F=5.3183, p=0.030)$, being significantly decreased by $40 \%$ DR across all ILSXISS strains. No significant genotype or treatment effects were detected for Bhmt1, Bhmt2 or Sahh (Figs. 3i-k, Table S2).

Protein levels of $\mathrm{H}_{2}$ S-production enzymes in ILSXISS and $\mathrm{C} 57 \mathrm{BL} / 6 \mathrm{~J}$ mice following $40 \% \mathrm{DR}$

Studies in $\mathrm{C} 57 \mathrm{BL} / 6 \mathrm{~J}$ mice have repeatedly shown that generation of hepatic $\mathrm{H}_{2} \mathrm{~S}$ is driven primarily through CSE and CBS, with CSE appearing to be the predominant enzymatic source (e.g. Mani et al. 2014). We subsequently compared hepatic protein levels of CSE, CBS and MPST in TejJ89, TejJ48 and TejJ114 mice with levels in C57BL/6J mice under AL feeding and 40\% DR. CSE protein levels (Fig. 4a) were significantly altered by both genotype $(F=14.845, p<0.001)$ and treatment $(F=5.559, p=$ $0.024)$, with a significant treatment by genotype interaction present $(F=5.990, p=0.002)$. CSE levels were significantly higher in $\mathrm{C} 57 \mathrm{BL} / 6 \mathrm{~J}$ mice relative to all ILSXISS strains ( $p<0.001$, in all cases), with no differences in CSE levels observed between 


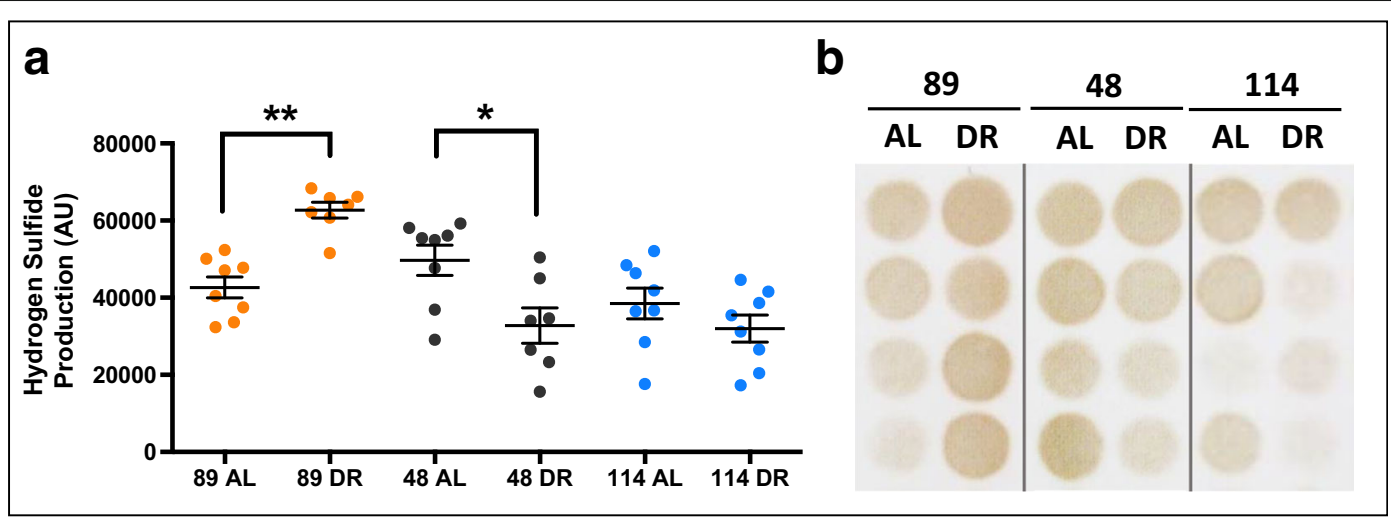

Fig. 1 Strain-specificity exists in hepatic $\mathrm{H}_{2} \mathrm{~S}$ production following $40 \%$ dietary restriction in female ILSXISS mice. a Hepatic $\mathrm{H}_{2} \mathrm{~S}$ production levels in TejJ89, TejJ48 and TejJ114 mice on AL or $40 \%$ DR, as quantified by densitometry analysis of lead acetate assay results. b Representative images of lead acetate precipitates

ILSXISS strains. CSE protein levels were elevated by $40 \%$ DR but only significantly so in C57BL/6J mice $(p=0.002)$. Hepatic CBS levels were also affected by genotype $(F=6.451, p=0.001)$ but not by treatment $(F=0.037, p=0.848)$, with TejJ89 mice having increased CBS levels relative to both TejJ114 ( $p=$ 0.002) and C57BL/6J ( $p=0.016)$ mice (Fig. 4b). MPST levels were significantly altered by both genotype $(F=12.984, p<0.001)$ and treatment $(F=$ $8.812, p=0.005)$, with a significant genotype by treatment interaction effect $(F=9.848, p<0.001)$ also observed (Fig. 4c). Hepatic MPST levels were significantly elevated in TejJ89 mice compared with all other genotypes $(p<0.001$, in all cases). The elevated $\mathrm{H}_{2} \mathrm{~S}$ levels observed in TejJ89 mice under $40 \%$ DR was associated with a significant elevation in hepatic MPST levels relative to TejJ89 AL mice (Fig. 4c, $p<0.001$ ), but $40 \%$ DR did not alter MPST levels significantly in any other genotype compared with their appropriate AL controls. We subsequently determined hepatic MPST activity within our ILSXISS mouse strains (Fig. S2), but no genotype $(F=0.144, p=0.707)$ nor treatment $(F=2.755, p=$ 0.081 ) effect was observed. Our findings indicate that significant genotype-specific differences exist in protein levels of the primary cellular $\mathrm{H}_{2} \mathrm{~S}$ generating enzymes CSE, CBS and MPST within mouse liver (Fig. $4 \mathrm{a}-\mathrm{c}$ ). The increased $\mathrm{H}_{2} \mathrm{~S}$ levels following $40 \%$ DR in strain TejJ89 was associated with an increase in MPST protein levels, but not in CSE (significantly elevated in C57BL/6J mice under $40 \%$ DR) or CBS levels, and that protein levels of these $\mathrm{H}_{2} \mathrm{~S}$ generating formed in the assay; darker precipitates indicate higher hepatic $\mathrm{H}_{2} \mathrm{~S}$ production capacity. TejJ89 data in orange, TejJ48 data in black, TejJ114 data in blue. Error bars represent SEM. ${ }^{*} p<0.05$, $* * p<0.01$

enzymes were unresponsive to $40 \%$ DR in strains TejJ48 and TejJ114.

\section{Discussion}

A reduction in the intake of calories or in the intake of macro- or micronutrients, termed here as dietary restriction (DR), is currently the most widely employed experimental intervention to modulate ageing. Indeed, DR has been shown to extend lifespan and healthspan in an evolutionary diverse group of organisms (Fontana and Partridge 2015; Speakman and Mitchell 2011), and has also been shown to provide a number of beneficial health effects in humans (Fontana et al. 2004; Fontana et al. 2007). However, it is still not understood how DR mechanistically elicits its beneficial effects. In addition, a number of studies, particularly in mice, report that the DR effect on lifespan and healthspan can vary significantly depending on genetic background (Forster et al. 2003; Goren et al. 2004; Hempenstall et al. 2010; Liao et al. 2010; Mitchell et al. 2016; Rikke et al. 2010; Swindell 2012; Turturro et al. 1999). It is believed that better understanding of the basis of this genetic variation during DR may be important if we hope to translate experimental findings from (typically) highly inbred mouse models to genetically heterogenous humans (Selman and Swindell 2018).

In this study, we investigated the potential relevance of Hydrogen sulfide $\left(\mathrm{H}_{2} \mathrm{~S}\right)$ in DR-induced lifespan by comparing genetically distinct ILSXISS recombinant inbred mouse strains that have been reported to show 


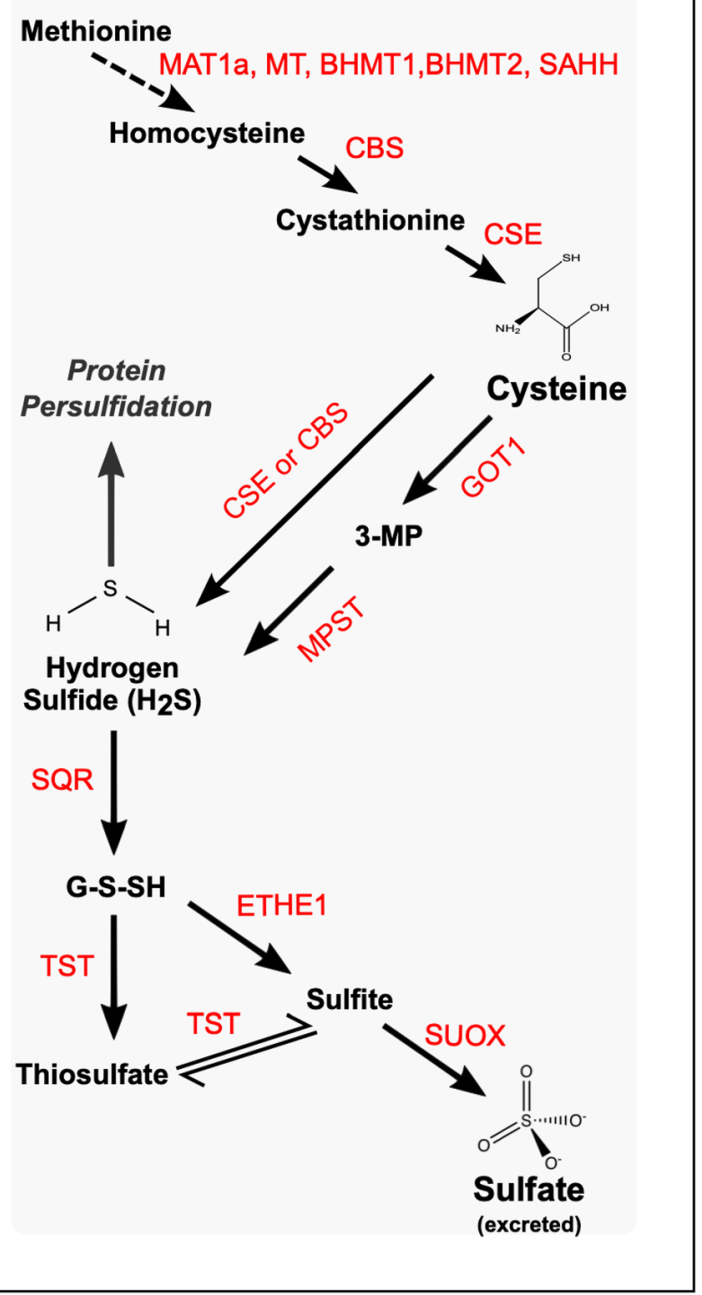

Fig. 2 Molecular pathways involved in the enzymatic production of $\mathrm{H}_{2} \mathrm{~S}$ from amino acid metabolism and subsequent elimination of $\mathrm{H}_{2} \mathrm{~S}$ by components of the sulphide disposal unit. Enzymes in red. MAT1a, methionine adenosyltransferase 1A; MT, methyl transferase; SAHH, S-adenosylhomocysteine hydrolase; BHMT1, betaine-homocysteine S-methyltransferase 1; BHMT2, betainehomocysteine S-methyltransferase 2 ; CBS, cystathionine- $\beta$ synthase; CSE, cystathionine- $\gamma$-lyase; GOT1, glutamicoxaloacetic transaminase 1; MPST, 3-mercaptopyruvate sulfurtransferase; SQR, sulphide:quinone oxidoreductase; TST, thiosulfate sulfurtransferase; ETHE1, ethylmalonic encephalopathy 1 protein; SUOX, sulfite oxidase

significant variation in their lifespan under $40 \%$ DR, ranging from life extension to no response, through to life shortening (Liao et al. 2010; Rikke et al. 2010). A number of studies have now reported genetic or pharmacological interventions that modulate $\mathrm{H}_{2} \mathrm{~S}$ levels can profoundly impact longevity in model organisms (Hine and Mitchell 2015; Miller and Roth 2007; Qabazard et al. 2013; Shaposhnikov et al. 2018; Wei and Kenyon 2016) and protect against age-associated dysfunction (Latorre et al. 2018; Wang et al. 2019; Zhan et al. 2018). In addition, increased hepatic $\mathrm{H}_{2} \mathrm{~S}$ is a conserved phenotype in long-lived genetic mouse mutants (Hine et al. 2017), is increased significantly by DR in C57BL/6J and DBA/2 mice (Hine et al. 2015; Mitchell et al. 2016) and appears essential for mediating the beneficial effects of DR (Hine et al. 2015). We found that hepatic $\mathrm{H}_{2} \mathrm{~S}$ was only elevated in female mice from strain TejJ89 under long-term 40\% DR; TejJ89 is the single ILSXISS strain in our study reported to show DRinduced longevity (Liao et al. 2010; Rikke et al. 2010). In contrast, strain TejJ48 reported to be refractory to 40\% DR (Liao et al. 2010; Rikke et al. 2010) showed a significant reduction in hepatic $\mathrm{H}_{2} \mathrm{~S}$ when exposed to $40 \%$ DR. In strain TejJ114 reported to show lifespan shortening under 40\% DR (Liao et al. 2010; Rikke et al. 2010), we observed no DR-associated difference in hepatic $\mathrm{H}_{2} \mathrm{~S}$ production relative to AL mice. However, no treatment nor interaction effect was observed in kidney $\mathrm{H}_{2} \mathrm{~S}$ production, suggesting tissue-specificity exists in the impact of DR on $\mathrm{H}_{2} \mathrm{~S}$ production in mice, in contrast to findings $\left(\mathrm{H}_{2} \mathrm{~S}\right.$ concentration) previously reported in F344 rats under DR (Wang et al. 2016). In addition, significant strain-specificity in $\mathrm{H}_{2} \mathrm{~S}$ production was also observed, being elevated in strain TejJ89 relative to both TejJ48 and TejJ114 in the liver and elevated in TejJ89 compared with TejJ48 in the kidney. Our findings indicate that TejJ89 mice show a similar association between increased hepatic $\mathrm{H}_{2} \mathrm{~S}$ production and extended lifespan under DR reported in other mouse strains such as C57BL/6J and DBA/2 (Mitchell et al. 2016). Consequently, our findings do further support the premise that elevated hepatic $\mathrm{H}_{2} \mathrm{~S}$ levels may be an important mediator of the beneficial effects of DR (Hine et al. 2015; Hine and Mitchell 2015).

To further investigate the potential processes underlying these strain-specific differences in $\mathrm{H}_{2} \mathrm{~S}$ following $40 \% \mathrm{DR}$, we examined a suite of $\mathrm{H}_{2} \mathrm{~S}$-producing and degrading enzymes at the transcript and protein level within ILSXISS mice. The predominately cytosolic enzymes cystathionine $\gamma$-lyase (CSE or CGL) and cystathionine $\beta$-synthase (CBS) are the main sources of $\mathrm{H}_{2} \mathrm{~S}$ within cells (Carter and Morton 2016), and mice carrying genetic defects in these enzymes are prone to a number of pathologies (Hine et al. 2018). In particular, elevated hepatic $\mathrm{H}_{2} \mathrm{~S}$ following DR correlates with transcript and protein levels of CSE (Derous et al. 2017; 
Fig. 3 ILSXISS mouse strains exhibit differential transcriptional regulation of $\mathrm{H}_{2} \mathrm{~S}$-production and elimination enzymes following $40 \%$ DR. Hepatic mRNA gene expression (presented as Delta $\mathrm{Ct}$ values, a lower Delta $\mathrm{Ct}$ indicates a higher number of mRNA transcripts for that particular gene) of $\mathrm{H}_{2} \mathrm{~S}$-producing (a-d), $\mathrm{H}_{2}$ S-eliminating (e-g) and methionine to cysteine conversion (h-k) genes in TejJ89, TejJ48 and TejJ114 mice under AL feeding or $40 \%$ DR. TejJ89 data in orange, TejJ48 data in black, TejJ114 data in blue. Error bars represent SEM. $* p<0.05$, * * $p<0.01$, $* * * p<0.001$. Genotype (TejJ89, TejJ48 or TejJ114) and Treatment (AL or DR). See Table S1 for statistical output. Cse, cystathionine- $\gamma$-lyase; $C b s$, cystathionine- $\beta$-synthase; $M p s t$, 3-mercaptopyruvate sulfurtransferase; Got1, glutamicoxaloacetic transaminase 1 ,

Ethe1, ethylmalonic encephalopathy 1 protein, $T s t$, thiosulfate sulfurtransferase; Suox, sulfite oxidase; Matla, methionine adenosyltransferase 1A; Bhmt1, betainehomocysteine Smethyltransferase 1; Bhmt2, betaine-homocysteine Smethyltransferase 2; Sahh, Sadenosylhomocysteine hydrolase

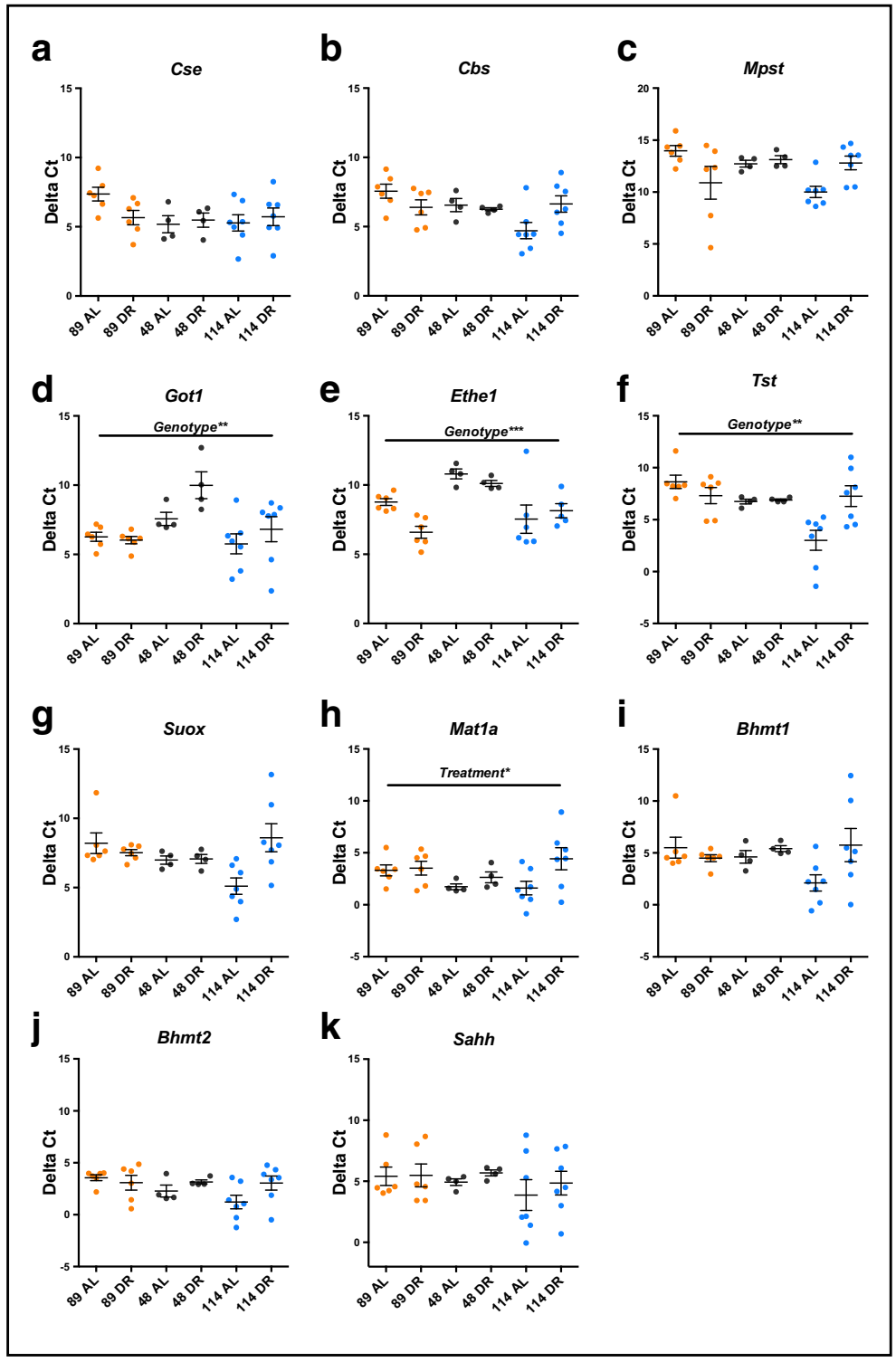

Wang et al. 2016), and similarly CSE levels are elevated in several long-lived mouse mutants (Hine et al. 2017). Perhaps surprisingly, we did not observe any genotype or treatment effects on transcript levels of $C s e, C b s$ or Mpst, although several significant genotype and genotype by treatment interaction effects (Cbs, Mpst, Tst, Suox) were detected, typically with TejJ89 AL mice having significantly reduced expression compared with TejJ114 AL mice. At the protein level, CSE was significantly elevated in C57BL/6J mice compared with all ILSXISS strains, with $40 \%$ DR further increasing CSE levels within the liver of C57BL/6J mice. However, $40 \%$ DR did not have any effect on hepatic CSE levels in ILSXISS mice. Hepatic CBS protein levels were unaffected by $40 \%$ DR across all genotypes studied. Given that both CSE and CBS levels were unaffected by $40 \%$ DR in strain TejJ89 despite the DR-associated increase in $\mathrm{H}_{2} \mathrm{~S}$ production, we subsequently investigate 3-mercaptopyruvate sulfurtransferase (MPST). This is the third $\mathrm{H}_{2} \mathrm{~S}$-producing enzyme within cells but its role has been much less well characterised relative to both CSE and CBS, particularly in the context of ageing and DR. CSE and CBS primarily remain cytoplasmic under normal physiological conditions, whereas MPST can localise to mitochondria and exhibits a profound influence over mitochondrial-specific metabolism and $\mathrm{H}_{2} \mathrm{~S}$ 
Fig. 4 40\% DR significantly increases cystathionine gammalyase (CSE) within the liver of C57BL/6J mice but significantly increases 3-mercaptopyruvate sulfurtransferase (MPST) within the liver of TejJ89 mice. Hepatic protein levels of CSE (a), cystathionine- $\beta$-synthase (CBS) (b) and MPST (c) in TejJ89 $(n=$ 6), TejJ48 $(n=4)$, TejJ114 $(n=6)$ and $\mathrm{C} 57 \mathrm{BL} / 6 \mathrm{~J}(n=4) \mathrm{AL}$ and $40 \%$ DR mice. TejJ89 data in orange, TejJ48 data in black, TejJ114 data in blue, C57BL/6J data in light grey. Error bars represent SEM. $* p<0.05$, $* * p<0.01, * * * p<0.001$. Genotype (TejJ89, TejJ48, TejJ114 or C57BL/6J) and treatment (AL or DR)

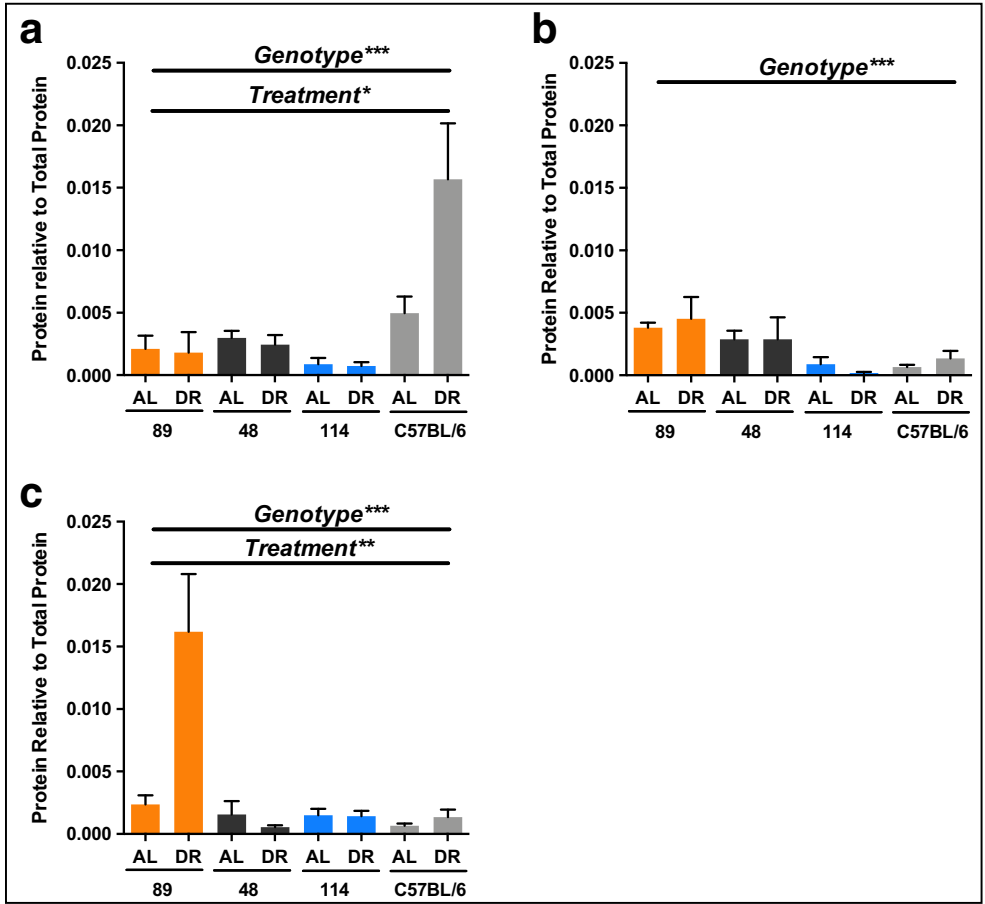

levels (Kimura 2014). Furthermore, while CSE and CBS work in concert to convert homocysteine into $\mathrm{H}_{2} \mathrm{~S}$ via step-wise reactions, MPST generates $\mathrm{H}_{2} \mathrm{~S}$ from a distinct substrate, 3-mercaptopyruvate (Renga 2011; Tao et al. 2017). We found MPST to be significantly increased in the liver of TejJ89 mice under $40 \%$ DR, although it was unaffected by DR in strains TejJ48, TejJ114 or in C57BL/6J mice. Precisely why C57BL/ $6 \mathrm{~J}$ mice and TejJ89 mice appear to have distinct mechanistic routes (elevated CSE or elevated MPST respectively) to achieve the same outcome of elevated hepatic $\mathrm{H}_{2} \mathrm{~S}$ under $40 \%$ DR still needs to be determined.

There are of course some caveats to our findings, not least that this work is highly correlational. As discussed elsewhere, the variation in phenotypic responses to DR across different mouse strains is quite broad (Mitchell et al. 2016; Selman and Swindell 2018; Swindell 2012). We examined females and then only in three strains of ILSXISS mice, albeit strains that represent the variety of lifespan responses reported in the original two studies (Liao et al. 2010; Rikke et al. 2010). We were vigilant in our choice of strains in this comparative study, choosing those that showed a similar direction of response across both studies. In addition, and as discussed in detail elsewhere (Selman and Swindell 2018), significant differences in experimental design and husbandry practices existed between the original studies. Consequently, a fuller investigation of the lifespan response to DR in ILSXISS mice and the potential relevance of $\mathrm{H}_{2} \mathrm{~S}$ production, particularly under graded levels of DR, is warranted, but will be a major undertaking (Selman and Swindell 2018). In addition, it will also be interesting to investigate precisely how $\mathrm{H}_{2} \mathrm{~S}$ production varies in different tissues and in different cellular locations following DR. These approaches may be made more feasible with the advent of novel chemical probes to determine $\mathrm{H}_{2} \mathrm{~S}$ in vivo (Arndt et al. 2017; Lau et al. 2019). However, irrespective of these caveats, we have shown that endogenous $\mathrm{H}_{2} \mathrm{~S}$ levels and associated signalling pathways differ significantly depending on genetic background in mice under both $\mathrm{AL}$ and $\mathrm{DR}$ conditions. Our data suggest that, similar to previous reports, increased $\mathrm{H}_{2} \mathrm{~S}$ production and/or metabolism is a conserved mechanism through which DR acts to increase lifespan in mice (Hine et al. 2017; Hine and Mitchell 2015), but the precise cellular processes that regulate $\mathrm{H}_{2} \mathrm{~S}$ production and elimination under DR appear highly strain- (and potentially tissue-) specific.

Acknowledgements We thank the animal care staff (CRF, University of Glasgow), Dr. Amy Valentine, Mrs. Kate Griffiths, Professor Lorna Harries and Dr. Ben Lee.

Authors' contributions SEW, LM, WAS, DEM, RNC and CH performed all experiments and analysed the data. SEW co-wrote 
the manuscript. NMM and JRM provided critical reagents. RNC, $\mathrm{CH}$, NMM and JRM edited the manuscript. CS designed the studies, co-wrote and edited the manuscript.

Funding information This work was supported through a Medical Research Council Precision Medicine Doctoral Training Program in Precision Medicine to SEW (Reference MR/N013166/1), a Wellcome Trust Biomedical Vacation Scholarship to DEM (Reference 213310/Z/18/Z), a NIH/NIA grant to CH (Reference AG050777), a Wellcome Trust Investigator award (Reference 100981/Z/13/Z) to NMM and start-up funds from the University of Glasgow (College of Medical, Veterinary and Life Sciences) to CS.

\section{Compliance with ethical standards}

Conflict of interest The authors declare that they have no conflict of interest.

Open Access This article is licensed under a Creative Commons Attribution 4.0 International License, which permits use, sharing, adaptation, distribution and reproduction in any medium or format, as long as you give appropriate credit to the original author(s) and the source, provide a link to the Creative Commons licence, and indicate if changes were made. The images or other third party material in this article are included in the article's Creative Commons licence, unless indicated otherwise in a credit line to the material. If material is not included in the article's Creative Commons licence and your intended use is not permitted by statutory regulation or exceeds the permitted use, you will need to obtain permission directly from the copyright holder. To view a copy of this licence, visit http://creativecommons.org/licenses/by/4.0/.

\section{References}

Arndt S, Baeza-Garza CD, Logan A, Rosa T, Wedmann R, Prime TA, Martin JL, Saeb-Parsy K, Krieg T, Filipovic, MR, Hartley RC, Murphy MP (2017) Assessment of $\mathrm{H}_{2} \mathrm{~S}$ in vivo using the newly developed mitochondria-targeted mass spectrometry probe MitoA. J Biol Chem 292:7761-7773. https://doi.org/10.1074/jbc.M117.784678

Carter RN, Morton NM (2016) Cysteine and hydrogen sulphide in the regulation of metabolism: insights from genetics and pharmacology. J Pathol 238:321-332. https://doi.org/10.1002/path.4659

Das A, Huang GX, Bonkowski MS, Longchamp A, Li C, Schultz MB, Kim LJ, Osborne B, Joshi S, Lu Y, Treviño-Villarreal JH, Kang MJ, Hung TT, Lee B, Williams EO, Igarashi M, Mitchell JR, Wu LE, Turner N, Arany Z, Guarente L, Sinclair DA (2018) Impairment of an endothelial NAD(+)-H2S signaling network is a reversible cause of vascular aging. Cell 173:74-89 e20. https://doi.org/10.1016/j.cell.2018.02.008

Derous D, Mitchell SE, Wang L, Green CL, Wang Y, Chen L, Han JDJ, Promislow DEL, Lusseau D, Douglas A, Speakman JR (2017) The effects of graded levels of calorie restriction: XI. Evaluation of the main hypotheses underpinning the life extension effects of $\mathrm{CR}$ using the hepatic transcriptome.
Aging (Albany NY) 9:1770-1824. https://doi.org/10.18632 /aging.101269

Fontana L, Meyer TE, Klein S, Holloszy JO (2004) Long-term calorie restriction is highly effective in reducing the risk for atherosclerosis in humans. Proc Natl Acad Sci U S A 101:6659-6663

Fontana L, Partridge L (2015) Promoting health and longevity through diet: from model organisms to humans. Cell 161: 106-118. https://doi.org/10.1016/j.cell.2015.02.020

Fontana L, Villareal DT, Weiss EP, Racette SB, Steger-May K, Klein S, Holloszy JO (2007) Calorie restriction or exercise: effects on coronary heart disease risk factors. A randomized, controlled trial. Am J Physiol Endocrinol Metab 293:E197-E202

Forster MJ, Morris P, Sohal RS (2003) Genotype and age influence the effect of caloric intake on mortality in mice. FASEB J 17:690-692

Gong H, Sun L, Chen B, Han Y, Pang J, Wu W, Qi R, Zhang TM (2016) Evaluation of candidate reference genes for RT-qPCR studies in three metabolism related tissues of mice after caloric restriction. Sci Rep 6:38513. https://doi.org/10.1038 /srep38513

Goren HJ, Kulkarni RN, Kahn CR (2004) Glucose homeostasis and tissue transcript content of insulin signaling intermediates in four inbred strains of mice: C57BL/6, C57BLKS/6, $\mathrm{DBA} / 2$, and 129X1. Endocrinology 145:3307-3323

Hempenstall S, Picchio L, Mitchell SE, Speakman JR, Selman C (2010) The impact of acute caloric restriction on the metabolic phenotype in male C57BL/6 and DBA/2 mice. Mech Ageing Dev 131:111-118. https://doi.org/10.1016/j.mad.2009.12.008

Hine C, Harputlugil E, Zhang Y, Ruckenstuhl C, Lee BC, Brace L, Longchamp A, Treviño-Villarreal JH, Mejia P, Ozaki CK, Wang R, Gladyshev VN, Madeo F, Mair WB, Mitchell JR (2015) Endogenous hydrogen sulfide production is essential for dietary restriction benefits. Cell 160:132-144. https://doi. org/10.1016/j.cell.2014.11.048

Hine C, Kim H-J, Zhu Y, Harputlugil E, Longchamp A, Souza Matos M, Ramadoss P, Bauerle K, Brace L, Asara JM, Ozaki CK, Cheng S-Y, Singha S, Han Ahn K, Kimmelman A, Fisher FM, Pissios P, Withers DJ, Selman C, Wang R, Yen K, Longo VD, Cohen P, Bartke A, Kopchick JJ, Miller R, Hollenberg AN, Mitchell JR (2017) Hypothalamic-pituitary axis regulates hydrogen sulfide production. Cell Metab 25: 1320-1333 e1325. https://doi.org/10.1016/j. cmet.2017.05.003

Hine C, Mitchell JR (2015) Calorie restriction and methionine restriction in control of endogenous hydrogen sulfide production by the transsulfuration pathway. Exp Gerontol 68 : 26-32. https://doi.org/10.1016/j.exger.2014.12.010

Hine C, Mitchell JR (2017) Endpoint or Kinetic Measurement of Hydrogen Sulfide Production Capacity in Tissue Extracts. Bio-Protoc 7(13):e2382. https://doi.org/10.21769 /BioProtoc. 2382

Hine C, Zhu Y, Hollenberg AN, Mitchell JR (2018) Dietary and endocrine regulation of endogenous hydrogen sulfide production: implications for longevity. Antioxid Redox Signal 28:1483-1502. https://doi.org/10.1089/ars.2017.7434

Ingram DK, de Cabo R (2017) Calorie restriction in rodents: caveats to consider. Ageing Res Rev 39:15-28. https://doi. org/10.1016/j.arr.2017.05.008

Kennedy BK, Steffen KK, Kaeberlein M (2007) Ruminations on dietary restriction and aging. Cell Mol Life Sci 64:13231328. https://doi.org/10.1007/s00018-007-6470-y 
Kimura H (2014) Production and physiological effects of hydrogen sulfide. Antioxid Redox Signal 20:783-793. https://doi. org/10.1089/ars.2013.5309

Latorre E, Torregrossa R, Wood ME, Whiteman M, Harries LW (2018) Mitochondria-targeted hydrogen sulfide attenuates endothelial senescence by selective induction of splicing factors HNRNPD and SRSF2. Aging (Albany NY) 10: 1666-1681. https://doi.org/10.18632/aging.101500

Lau GY, Barts N, Hartley RC, Tobler M, Richards JG, Murphy MP, Arndt S (2019) Detection of changes in mitochondrial hydrogen sulfide in vivo in the fish model Poecilia mexicana (Poeciliidae). Biol Open:8. https://doi.org/10.1242 /bio.041467

Lee HJ, Feliers D, Barnes JL, Oh S, Choudhury GG, Diaz V, Galvan V, Strong R, Nelson J, Salmon A, Kevil CG, Kasinath BS (2018) Hydrogen sulfide ameliorates aging-associated changes in the kidney. Geroscience 40:163-176. https://doi.org/10.1007/s11357-018-0018-y

Liao CY, Rikke BA, Johnson TE, Diaz V, Nelson JF (2010) Genetic variation in the murine lifespan response to dietary restriction: from life extension to life shortening. Aging Cell 9:92-95. https://doi.org/10.1111/j.1474-9726.2009.00533.x

Liao CY, Rikke BA, Johnson TE, Gelfond JA, Diaz V, Nelson JF (2011) Fat maintenance is a predictor of the murine lifespan response to dietary restriction. Aging Cell 10:629-639. https://doi.org/10.1111/j.1474-9726.2011.00702.x

Mair W, Dillin A (2008) Aging and survival: the genetics of life span extension by dietary restriction. Annu Rev Biochem 77:727-754. https://doi.org/10.1146/annurev.biochem.77.061206.171059

Mani S, Cao W, Wu L, Wang R (2014) Hydrogen sulfide and the liver. Nitric Oxide 41:62-71. https://doi.org/10.1016/j. niox.2014.02.006

Masoro EJ (2005) Overview of caloric restriction and ageing. Mech Ageing Dev 126:913-922

Miller DL, Roth MB (2007) Hydrogen sulfide increases thermotolerance and lifespan in Caenorhabditis elegans. Proc Natl Acad Sci U S A 104:20618-20622. https://doi.org/10.1073 /pnas.0710191104

Mitchell SJ, Madrigal-Matute J, Scheibye-Knudsen M, Fang E, Aon M, González-Reyes JA, Cortassa S, Kaushik S, Gonzalez-Freire M, Patel B, Wahl D, Ali A, Calvo-Rubio M, Burón MI, Guiterrez V, Ward TM, Palacios HH, Cai H, Frederick DW, Hine C, Broeskamp F, Habering L, Dawson J, Beasley TM, Wan J, Ikeno Y, Hubbard G, Becker KG, Zhang Y, Bohr VA, Longo DL, Navas P, Ferrucci L, Sinclair DA, Cohen P, Egan JM, Mitchell JR, Baur JA, Allison DB, Anson RM, Villalba JM, Madeo F, Cuervo AM, Pearson KJ, Ingram DK, Bernier M, de Cabo R (2016) Effects of sex, Strain, and Energy Intake on Hallmarks of Aging in Mice. Cell Metab 23:1093-1112. https://doi.org/10.1016/j.cmet.2016.05.027

Morton NM, Beltram J, Carter RN, Michailidou Z, Gorjanc G, McFadden C, Barrios-Llerena ME, Rodriguez-Cuenca S, Gibbins MTG, Aird RE, Moreno-Navarrete JM, Munger SC, Svenson KL, Gastaldello A, Ramage L, Naredo G, Zeyda M, Wang ZV, Howie AF, Saari A, Sipilä P, Stulnig TM, Gudnason V, Kenyon CJ, Seckl JR, Walker BR, Webster SP, Dunbar DR, Churchill GA, Vidal-Puig A, FernandezReal JM, Emilsson V, Horvat S (2016) Genetic identification of thiosulfate sulfurtransferase as an adipocyte-expressed antidiabetic target in mice selected for leanness. Nat Med 22:771-779. https://doi.org/10.1038/nm.4115
Mulvey L, Sands WA, Salin K, Carr AE, Selman C (2016) Disentangling the effect of dietary restriction on mitochondrial function using recombinant inbred mice. Mol Cell Endocrinol. https://doi.org/10.1016/j.mce.2016.09.001

Mulvey L, Sinclair A, Selman C (2014) Lifespan modulation in mice and the confounding effects of genetic background. J Genet Genomics 41:497-503. https://doi.org/10.1016/j.jgg.2014.06.002

Picca A, Pesce V, Lezza AMS (2017) Does eating less make you live longer and better? An update on calorie restriction. Clin Interv Aging 12:1887-1902. https://doi.org/10.2147/CIA.S126458

Qabazard B, Ahmed S, Li L, Arlt VM, Moore PK, Stürzenbaum SR (2013) C. elegans aging is modulated by hydrogen sulfide and the sulfhydrylase/cysteine synthase cysl-2. PLoS One 8: e80135. https://doi.org/10.1371/journal.pone.0080135

Renga B (2011) Hydrogen sulfide generation in mammals: the molecular biology of cystathionine-beta- synthase (CBS) and cystathionine-gamma-lyase (CSE). Inflamm Allergy Drug Targets 10:85-91

Rikke BA, Liao CY, McQueen MB, Nelson JF, Johnson TE (2010) Genetic dissection of dietary restriction in mice supports the metabolic efficiency model of life extension. Exp Gerontol 45: 691-701. https://doi.org/10.1016/j.exger.2010.04.008

Selman C, Swindell WR (2018) Putting a strain on diversity. EMBO J 37. https://doi.org/10.15252/embj.2018100862

Shaposhnikov M, Proshkina E, Koval L, Zemskaya N, Zhavoronkov A, Moskalev A (2018) Overexpression of CBS and CSE genes affects lifespan, stress resistance and locomotor activity in Drosophila melanogaster. Aging (Albany NY) 10:3260-3272. https://doi.org/10.18632/aging.101630

Speakman JR, Mitchell SE (2011) Caloric restriction. Mol Asp Med 32:159-221. https://doi.org/10.1016/j.mam.2011.07.001

Swindell WR (2012) Dietary restriction in rats and mice: a metaanalysis and review of the evidence for genotype-dependent effects on lifespan. Ageing Res Rev 11:254-270. https://doi. org/10.1016/j.arr.2011.12.006

Talaei F, van Praag VM, Henning RH (2013) Hydrogen sulfide restores a normal morphological phenotype in Werner syndrome fibroblasts, attenuates oxidative damage and modulates mTOR pathway. Pharmacol Res 74:34-44. https://doi. org/10.1016/j.phrs.2013.04.011

Tao B, Wang R, Sun C, Zhu Y (2017) 3-Mercaptopyruvate sulfurtransferase not cystathionine beta-synthase nor cystathionine gamma-lyase, mediates hypoxia-induced migration of vascular endothelial cells. Front Pharmacol 8:657. https://doi.org/10.3389/fphar.2017.00657

Turturro A, Witt WW, Lewis S, Hass BS, Lipman RD, Hart RW (1999) Growth curves and survival characteristics of the animals used in the biomarkers of aging program. $\mathrm{J}$ Gerontol A Biol Sci Med Sci 54:B492-B501

Wang SY, Wang WJ, Liu JQ, Song YH, Li P, Sun XF, Cai GY, Chen XM (2019) Methionine restriction delays senescence and suppresses the senescence-associated secretory phenotype in the kidney through endogenous hydrogen sulfide. Cell Cycle 18:1573-1587. https://doi.org/10.1080 /15384101.2019.1618124

Wang WJ, Cai GY, Ning YC, Cui J, Hong Q, Bai XY, Xu XM, Bu R, Sun XF, Chen XM (2016) Hydrogen sulfide mediates the protection of dietary restriction against renal senescence in aged F344 rats. Sci Rep 6:30292. https://doi.org/10.1038 /srep30292 
Wei Y, Kenyon C (2016) Roles for ROS and hydrogen sulfide in the longevity response to germline loss in Caenorhabditis elegans. Proc Natl Acad Sci U S A 113:E2832-E2841. https://doi.org/10.1073/pnas.1524727113

Weindruch R, Walford RL (1988) The retardation of aging and disease by dietary restriction. Charles C, Thomas, Springfield, Illinois

Yuan R, Tsaih SW, Petkova SB, Marin de Evsikova C, Xing S, Marion MA, Bogue MA, Mills KD, Peters LL, Bult CJ, Rosen CJ, Sundberg JP, Harrison DE, Churchill GA, Paigen B (2009) Aging in inbred strains of mice: study design and interim report on median lifespans and circulating
IGF1 levels. Aging Cell 8:277-287. https://doi.org/10.1111 j.1474-9726.2009.00478.x

Zhan JQ, Zheng LL, Chen HB, Yu B, Wang W, Wang T, Ruan B, Pan BX, Chen JR, Li XF, Wei B, Yang YJ (2018) Hydrogen sulfide reverses aging-associated amygdalar synaptic plasticity and fear memory deficits in rats. Front Neurosci 12:390. https://doi.org/10.3389/fnins.2018.00390

Publisher's note Springer Nature remains neutral with regard to jurisdictional claims in published maps and institutional affiliations. 